\title{
The Design of a Learning Process for Promoting Teamwork using Project-Based Learning and the Concept of Agile Software Development
}

\author{
https://doi.org/10.3991/ijet.v15i03.10480 \\ Puttida Sakulvirikitkul ${ }^{(凶)}$, Krich Sintanakul, Jiraphan Srisomphan \\ King Mongkut's University of Technology North Bangkok, \\ Bangkok, Thailand \\ puttida0103@gmail.com
}

\begin{abstract}
The design of a learning process for promoting teamwork using project-based learning and the concept of Agile software development had the following objectives: a) analyze and synthesize the conceptual framework for a learning process for computer students aimed at promoting teamwork using project-based learning and the concept of Agile software development; and b) a evaluate the suitability of a learning management model design for computer students aimed at promoting teamwork via project-based learning and the concept of Agile software development by 10 experts in which the model consists of six parts: 1) preparation; 2) group division; 3) project-based learning; 4) an Agile working process; 5) teamwork; and 6) an assessment process derived from the result of the assessment of the suitability of the learning style, which indicated the highest level. According to the assessment result, the model can be applied to learning management.
\end{abstract}

Keywords-Project-Based Learning, Agile Software Development

\section{$1 \quad$ Introduction}

The evolution of information and technology in today's world continues to grow in strength and to develop rapidly on a journey of digital transformation, leading to the great challenge as to how to develop personnel with digital and IT skills. Additionally, as the Thai government has implemented policies to develop human resources in order to produce a high-quality workforce to move the nation forwards, teachers need to develop an instructional model that focuses on enabling students to develop practical skills which they can apply to learning to real-life situations, as required by the National Scheme of Education B.E. 2560-2579 (201-2036). In this regard, there are two development goals - students' character development and the development of 21 st-century skills - that are essential for people in the digital era. According to a survey by the World Economic Forum [1] which analyzed workforce demand as well as the approach 
to technology in large organizations worldwide, the concept of 21 st-century skills comprises 16 aspects [2] [3][4], including essential traits such as communication and interpersonal and teamwork skills.

Project-based learning focusing on interpersonal and teamwork skills is often used in learning management and is designed to provide students with practical training and real-world experience. This will allow students to develop problem-solving skills, creativity in the workplace, and planning skills. Based on a survey of Thai teachers in the field of computer programming using project-based learning, the model of learning management used did not function optimally, with a lack of digital tool applications for counselling [5] [6] [7].

The concept of Agile Scrum software development is to provide flexible stages with regard to the working process, supporting the best methodology for each unique situation, focusing on team support where team members are spread out over different rooms, locations, or time zones, as well as conveying information within a development team. Schwaber and Sutherland [8] found that adopting the Agile approach to learning management can assist students in engaging in effective analysis and problem-solving, as well as preparing them for changes that might occur in the workplace. In addition, the adoption of the Agile methodology supports working in collaboration, exchanging ideas, and teamwork [9].

According to the survey, case studies, and problems encountered during the study process, the researcher devised ideas to develop learning management to promote $21 \mathrm{st}-$ century skills for students in the form of teamwork, planning, problem-solving, socialization, and forms of digital communication, while teachers provide the learning management methods along with the technology.

\section{Research Objective}

- To analyze and synthesize the conceptual framework for a learning process for computer students aimed at promoting teamwork using project-based learning and the concept of Agile software development

- To evaluate the suitability of a learning management model design for computer students aimed at promoting teamwork via project-based learning and the concept of Agile software development.

\section{$3 \quad$ Literature Review}

\subsection{Teamwork development}

Teamwork development is an adaptive, dynamic, and episodic process that encompasses the thoughts, feelings, and behaviors among team members while they interact towards a common goal. Teamwork is necessary for effective team performance, as it determines how tasks and goals are accomplished in a team context [10] [6] [11]. 
The use of critical inquiry was proposed by Israt Fatema and Kazi Sakib [12] in their study, "Factors Influencing Productivity of Agile Software Development Teamwork: A Qualitative System Dynamics Approach". They believed that teamwork productivity determines the overall project performance in an Agile software development process. Therefore, it was of interest to study team members' productivity. Agile team members should be taught to interpret and manage productivity factors regularly, as they are selfmanaged. Productivity improvement programs would become effective only if all the variables were simultaneously controlled and monitored. The Scrum Guide [8] indicates that a Scrum Team consists of a Product Owner, the Development Team, and a Scrum Master. Scrum Teams is a type of team that is self-organizing and cross-functional. In contrast to the component team approach, a cross-functional team consists of people from different functional areas of the company.

\subsection{Project-based learning}

Project-based learning (PJBL) is a teaching approach designed to give students the opportunity to develop knowledge and skills through exposure to real-world situations, including study, exploration, experimentation, demonstration, creation, and development, for the production of a significant piece of work that students can use in a practical way. Teachers use the PJBL method to encourage students, make suggestions, and to give them advice with regard to improving their thinking processes [13] [28]. The characteristics of PJBL are as follows [14] [15] [16]:

Inter-disciplinary: PJBL focuses on engaging students with real-world problems. This is an interdisciplinary approach because real-world challenges are rarely solved using information or skills from a single subject area. Projects require students to engage in inquiry, solution building, and product construction to help address the realworld issue or challenge presented. As students work, they often use content knowledge and skills from multiple academic domains to successfully complete the project.

Rigorous: PJBL requires the application of knowledge and skills, not just recall or recognition. Unlike rote learning that relates to a single fact, PJBL is more complex and can be used to ensure that students apply a variety of academic content in new contexts. As students engage in a project, they follow a process that begins with inquiry. Inquiry leads to deeper learning, not just related to academic content but also related to the use of content in real-world situations. Inquiry processes can help lead to the development of solutions that address the problem/challenge posed by the project, and the creation of products to communicate solutions to an audience based upon the application of content and skills.

Student-centered: In PJBL, the role of the teacher shifts from being a content-deliverer to being a facilitator/project manager. Students work more independently through the PJBL process than in a traditional learning situation, with the teacher providing support only when needed. Students are encouraged to make their own decisions about how best to do the work and demonstrate their understanding. The PJBL process fosters student independence, ownership of his/her work, and the develoment of 21 st-century/workplace skills. 


\subsection{Agile scrum software development}

Scrum is a process framework that has been used since the early 1990s to manage work with regard to complex products. Scrum is not a process, technique, or definitive method. Rather, it is a framework within which various processes and techniques can be employed. Scrum makes clear the relative efficacy of product management and work techniques so that the product, the team, and the working environment can be continuously improved [17] [18].

The Scrum framework consists of Scrum Teams and their associated roles, events, artifacts, and rules. Each component within the framework serves a specific purpose and is essential to Scrum's success and usage. Successful use of Scrum depends on people becoming more proficient in living by these five values; Courage, Commitment, Focus, Openness, and Respect. People personally commit to achieving the goals of the Scrum Team. The Scrum Team members have the courage to act appropriately and work on tough problems. Everyone focuses on the work of the Sprint (Repeatable work cycle in scrum methodology) and the goals of the Scrum Team. The Scrum Team and its stakeholders agree to be open about all the work and the challenges whilst engaged in the work. Scrum Team members respect each other and are capable, independent people [8] [9].

\section{$4 \quad$ Methodology}

The research methodology was divided into the two phases according to the research objectives. These are as follows:

Phase 1: The steps associated with analyzing and synthesizing the design of the learning process for promoting teamwork using PJBL and the concept of Agile software development were as follows:

- Synthesize documents relating to PJBL, based on the work of Bell [5], Boon [6], Helm [7], and Pinanta \& Prachyanun [27]

- Complete a review of the literature related to the PJBL process written by Katz and Chard [19], Stix and Hrbek [20], Monchai [13], Puttida and [21] and Davis [22]

- Study the concepts of Agile software development from related research papers and "The Scrum Guide" by Schwaber and Sutherland [8],[9],[21]

- Design the new learning process entitled the "PJBL and SCRUM (PJBL-SCRUM) for Promoting Teamwork".

Phase 2: The steps associated with evaluating the suitability of the learning process for promoting teamwork using PJBL and the concept of Agile software development were as follows:

- Create a tool to evaluate the suitability of the learning process.

- Propose developments with regard to the learning process. This involved the consideration of and evaluation of the suitability of the process involving 10 experts who hold doctoral degrees, work as lecturers at universities, and have at least 10 years' 
relevant experience. The group consisted of three experts in literacy and four experts in educational technology.

- Evaluate the suitability of the learning management model for computer students by having focus group discussions with the 10 experts.

- Analyze the results of the evaluation of the suitability of the learning process of critical inquiry through digital storytelling in order to enhance digital literacy by using mean $(\bar{x})$ and standard deviation (S.D.) measures. A five-point Likert scale was used to assess the appropriateness of the various activities.

\section{$5 \quad$ Research Findings}

5.1 Phase 1: The design of a learning process for promoting teamwork using PJBL and the concept of Agile software development

The learning process for promoting teamwork using PJBL and the concept of Agile software development consists of the following components:

PJBL process: The researcher surveyed the literature related to PJBL in order to synthesize and design learning processes using a study of methods, concepts, and theories derived from case studies and other related research papers relating to PJBL.

Table 1. The synthesis of the PJBL process

\begin{tabular}{|l|c|c|c|c|c|}
\hline \multirow{2}{*}{\multicolumn{1}{c|}{ PJBL process }} & \multicolumn{5}{|c|}{ The synthesis of the PJBL process } \\
\cline { 2 - 6 } & Katz and Chard & $\begin{array}{c}\text { Stix and } \\
\text { Hrbek }\end{array}$ & Monchai & $\begin{array}{c}\text { Puttida and } \\
\text { Krich }\end{array}$ & Davis \\
\hline 1) Project topic & $\checkmark$ & & $\checkmark$ & $\checkmark$ & $\checkmark$ \\
\hline 2) Reviewing documents & $\checkmark$ & $\checkmark$ & $\checkmark$ & $\checkmark$ & $\checkmark$ \\
\hline 3) Planning and drafting & $\checkmark$ & $\checkmark$ & $\checkmark$ & $\checkmark$ & $\checkmark$ \\
\hline 4) Working process & $\checkmark$ & $\checkmark$ & $\checkmark$ & $\checkmark$ & $\checkmark$ \\
\hline 5) Writing the report & $\checkmark$ & & $\checkmark$ & $\checkmark$ & $\checkmark$ \\
\hline 6) Presentation & $\checkmark$ & $\checkmark$ & $\checkmark$ & $\checkmark$ & $\checkmark$ \\
\hline
\end{tabular}

As shown in Table 1, the synthesis of the PJBL process consisted of the following six steps:

- Project topic: Students receive project topics from stakeholders and explore all the project requirements from the stakeholders.

- Reviewing documents: Team members jointly explore the existing knowledge of team members and then study the documents to be able to develop the project.

- Planning and drafting: The team engages in project planning. The operating period is established to be in the form of project presentation documents.

- Working process: Production of the work based on the plan begun in agreement with the stakeholders.

- Writing the report: The team writes a summary report with regard to the project's performance. Stakeholders are aware of the steps to be completed.

- Presentation: Presenting the project achievements to the stakeholders. 
The concept of Agile software development: The researcher surveyed the literature related to the concept of Agile software development with regard to design learning processes. This refers to a group of software development methodologies based on iterative development, where requirements and solutions evolve through collaboration between self-organizing cross-functional teams.

Agile methods or Agile processes generally promote a disciplined project management process that encourages frequent inspection and adaptation, a leadership philosophy that encourages teamwork, self-organization and accountability, a set of engineering best practices intended to allow for the rapid delivery of high-quality software, and a business approach that aligns development with customer needs and company goals [8] [9].

Scrum is a subset of Agile software development. It is a lightweight process framework for Agile development and is the one most widely-used. A Scrum process is distinguished from other Agile processes through the use of specific concepts and practices, divided into the three categories of Roles, Artifacts, and Time Boxes. These and other terms used in Scrum are defined below. Scrum is most often used to manage complex software and product development, using iterative and incremental practices. Scrum significantly increases productivity and reduces time-to-benefits compared with classic "waterfall" processes. Scrum processes enable organizations to adjust smoothly to rapidly-changing requirements, and produce a product that meets evolving business goals [9].

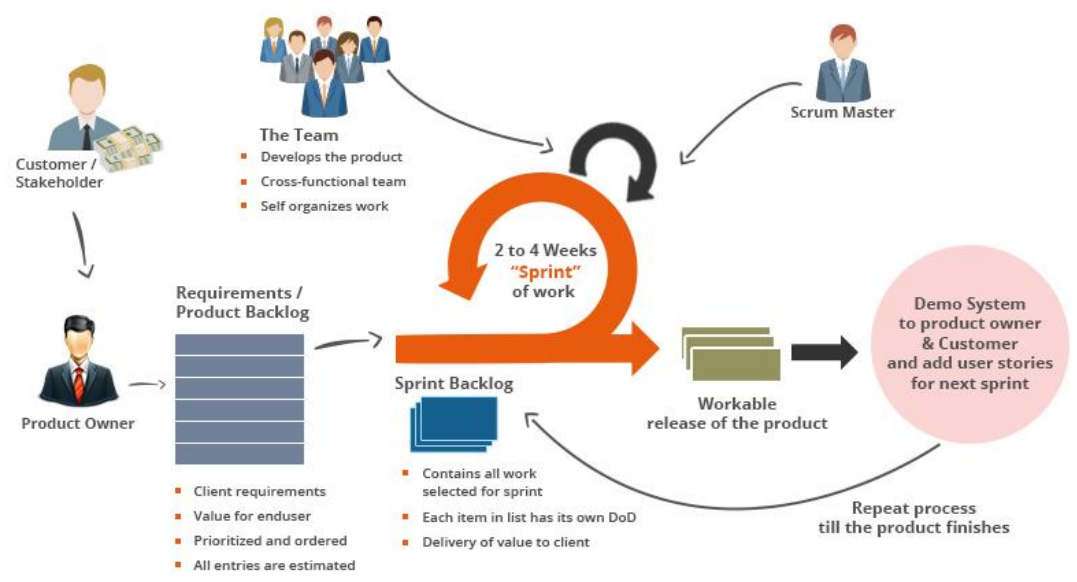

Fig. 1. The Scrum processes [9]

The Scrum processes shown in Figure 1 are as follows [8] [9]:

- Product backlog: Items are often large and general in nature and they can come and go as priorities change. Because of this fluid environment, product backlog refinement is an ongoing activity throughout a Scrum project.

- Sprint planning: Each sprint begins with a time-boxed meeting entitled sprint planning. In this meeting, the Scrum team selects and understands the work to be done 
in the sprint. The entire team attends the sprint planning meeting. The product owner and the development team members discuss each item selected for development from the product backlog, and come to a shared understanding of how the particular item should be developed so that it can deliver the maximum business value in the sprint. This is done by understanding the "Definition of Done" stated for the item. The recommended time for the sprint planning meeting is two hours or less for one week of sprint duration. As the meeting is time-boxed, the success of the sprint planning meeting depends on the quality of the product backlog going in. This is why product backlog refinement is so important.

- Daily Scrum: The development team uses the Daily Scrum meeting to ensure that they are on track for that sprint. They hold the meeting at the same time and place every day. The meeting should be short and time-boxed for a maximum of 15 minutes.

- Sprint Review: At the end of each sprint, the Scrum team and stakeholders review the resulting product increment. This meeting is called a Sprint Review. The main point of discussion is the product increment that has been achieved during the sprint. Since the stakeholders are those who have a "stake" in the results, it is a good idea for them to attend this meeting. During the meeting, the team members demonstrate what they have developed during the sprint, and showcase the work to the product owner and stakeholders - if present - and obtain their approval. All "shippable" work is accepted, while rejected work is transferred back to the product backlog after reestimating it.

- Sprint Retrospective: At the end of each sprint, the Scrum team produce the sprint retrospective. During the retrospective, the team members review how the process went, including the effectiveness of intrapersonal relationships and the tools used. They talk about what went well and not so well, and they identify potential improvements. They then devise a plan for improving those aspects in the future. Remaining true to the Scrum framework, the Scrum team improves its own process rather than relying on others to provide direction.

Scrum was designed for a single team to be able to work at its optimal capacity while maintaining a sustainable pace. In the field, it was found that as the number of Scrum teams within an organization grew, the output (working product) and velocity of those teams began to fall (due to issues such as cross-team dependencies and duplication of work). It became obvious that a framework for effectively coordinating those teams was needed in order to achieve linear scalability. Scrum@Scale is designed to accomplish this goal via its scale-free architecture [8].

Scrum@Scale is designed to scale across the organization as a whole in terms of all departments, products, and services. It can be applied across multiple domains in all types of organizations in industry, government, or academia [8] [23].

A further aspect is Scrum of Scrum $(\mathrm{SoS})$. Depending upon the size of the organization or degree of implementation, more than one SoS may be needed to deliver a very complex product, as shown in Figure 2. In such cases, a Scrum of Scrum of Scrums (SoSoS) can be created out of multiple Scrums of Scrums. The SoSoS is an organic pattern for Scrum teams which is infinitely scalable. 


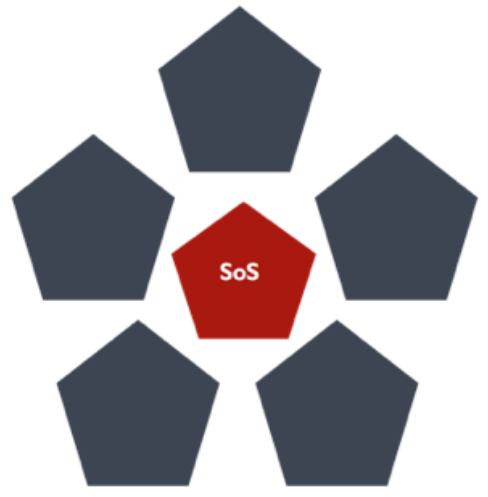

SoS of 5 Teams

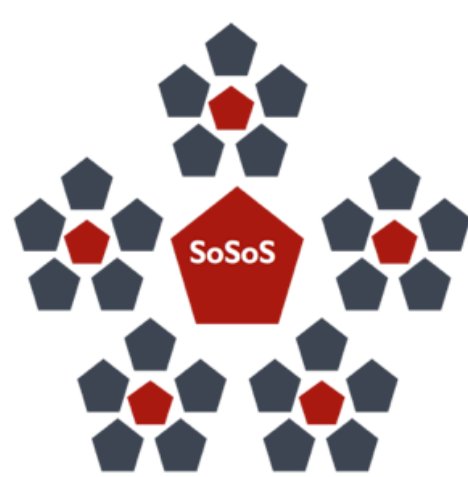

SoSos of 25 Teams

Fig. 2. Sample Diagram of Scrum of Scrums (SoS) [23]

The design of a learning process for promoting teamwork using PJBL and the concept of Agile software development (PJBL-SCRUM): After the conceptualization process, the researcher then integrated the PJBL process into a learning management process that promotes teamwork skills. The ultimate aim was to develop learners' thinking processes so that they learned to promote the skills of teamwork, planning, problem-solving, socialization, and forms of digital communication. The results from mapping of the learning process between PJBL and SCRUM are illustrated in Table 2.

Table 2. Mapping of the learning process between PJBL and SCRUM

\begin{tabular}{|l|c|c|c|c|c|c|}
\hline \multirow{2}{*}{ PJBL Process } & \multicolumn{5}{|c|}{ The Concept of Agile Software Development: SCRUM } \\
\hline & $\begin{array}{c}\text { Product } \\
\text { Backlog }\end{array}$ & $\begin{array}{c}\text { Sprint Plan- } \\
\text { ning }\end{array}$ & $\begin{array}{c}\text { Daily } \\
\text { Scrum }\end{array}$ & $\begin{array}{c}\text { Sprint } \\
\text { Review }\end{array}$ & $\begin{array}{c}\text { Sprint Retro- } \\
\text { spective }\end{array}$ & $\begin{array}{c}\text { Incremental } \\
\text { Product }\end{array}$ \\
\hline 1) Project topic & $\checkmark$ & & & & & \\
\hline 2) Reviewing documents & $\checkmark$ & & & & & \\
\hline 3) Planning and drafting & $\checkmark$ & & & & & \\
\hline 4) Working process & & $\checkmark$ & $\checkmark$ & $\checkmark$ & $\checkmark$ & \\
\hline 5) Writing the report & & & & & & $\checkmark$ \\
\hline 6) Presentation & & & & & & $\checkmark$ \\
\hline
\end{tabular}

According to the Mapping result in Table 2, learning process between PJBL and SCRUM, the model of the learning process for promoting teamwork using PJBL and the concept of Agile software development (PJBL-SCRUM). as presented in Figure 3. 




Fig. 3. Model of the PJBL-SCRUM online system

According to Figure 2, the PJBL-SCRUM model as incorporates six modules as the following:

1. Preparation module: The preparation involved offering students an orientation program to help smooth the transition to PJBL-SCRUM. This included explanations of learning concepts and activities encouraging students to develop perspectives and positive attitudes for meaningful activity participation, as well encouraging participative behavior corresponding to the concept of Agile software development.

2. Group division module: The process of dividing students into groups consisted of the following steps:

- Assessment of individual student's theoretical knowledge

- Mixed ability grouping

- Adjustment the group members voluntarily, subject to the conditions of the teacher

- All team members of each group to take part in goal-setting conversations

- Determination of roles and responsibilities based on SCRUM roles.

3. PJBL module: The PJBL process in which the learner must develop the project consisted of 6 steps as follows:

- Making project topic decision

- Reviewing documents

- Planning and drafting

- Working process

- Writing the report 
- Presentation

Students must learn according to the process described, by integrating the activities of the Agile Working Process as per the Scrum Framework.

4. Agile Working Process: As per the Scrum Framework module: In this step, the learners will perform the activities according to Agile Working Process as per the Scrum Framework in a PJBL context. The students will be able to access the PJBL-SCRUM system online. This is a tool that will help promote learning activities. The blended learning activity associated with PJBL-Scrum methods is shown in Table 3.

Table 3. Blended learning activity with PJBL-Scrum methods

\begin{tabular}{|c|c|c|}
\hline PJBL Process & SCRUM Activity & Activity Characteristics \\
\hline 1) Project topic & \multirow{3}{*}{ Product backlog } & \multirow{3}{*}{$\begin{array}{l}\text { Description of project/all work undertaken, with } \\
\text { the priorities set and managed by product owner. }\end{array}$} \\
\hline 2) Reviewing documents & & \\
\hline 3) Planning and drafting & & \\
\hline \multirow{6}{*}{ 4) Working process } & Sprint planning & $\begin{array}{l}\text { Team plan for selecting one of the product back- } \\
\text { log items in which the product owner dictates the } \\
\text { priority in terms of work items. The next step is } \\
\text { brainstorming to bring the product to life. }\end{array}$ \\
\hline & Sprint backlog & $\begin{array}{l}\text { Release planning for a complete product backlog, } \\
\text { set sprint goal. }\end{array}$ \\
\hline & Daily Scrum & $\begin{array}{l}\text { Group/team meetings on a daily basis to find out } \\
\text { the results of the previous day's work and to fore- } \\
\text { cast upcoming work. }\end{array}$ \\
\hline & Sprint Review & $\begin{array}{l}\text { Inspect the results of the work as well as collect } \\
\text { feedback for product development in the next } \\
\text { sprint phase. }\end{array}$ \\
\hline & Sprint retrospective & $\begin{array}{l}\text { Encourage all team members to review any forms } \\
\text { of the process and to share ideas as well as prob- } \\
\text { lems, such as where the team could improve the } \\
\text { product, service, or process. }\end{array}$ \\
\hline & Scrum of Scrums (SOS) & $\begin{array}{l}\text { Meeting of team members with the Scrum master } \\
\text { for assessment of progress or problems, as well as } \\
\text { undertaking an overview of all projects. }\end{array}$ \\
\hline 5) Writing the report & \multirow{2}{*}{ Incremental product release } & \multirow{2}{*}{$\begin{array}{l}\text { The sum of all the completed product backlog } \\
\text { items for release. }\end{array}$} \\
\hline 6) Presentation & & \\
\hline
\end{tabular}

Table 3 shows that the process of integrating learning activities between PJBL and Agile working in the form of a Scrum framework, based on the Scrum framework methodology (Scrum Events) [8]. In addition, the researcher improved teamwork skills by applying the Scrum of Scrums method to the Scrum framework. If the teams found obstructions caused by other teams, or wished to change the system in such a way as to affect the other sections or a third party, the scrum masters of each team would report those issues as well as changes, to the scrum masters (teachers). The process was used as a team-building activity associated with integration through the innovation development process based on the topic.

5. Student teamwork skill module: To promote project teams, team members should be part of a self-organizing, cross-functional team. By self-managing 
each scrum, the team decides how the group will work. Within this team, each member has clearly-determined responsibilities. This means that each team member is encouraged to show his or her opinion. Together, they can then arrive at a solution. The team should possess all the knowledge required to deliver a project. The assessment of teamwork skills will be assessed by students, teachers and the stakeholders. Assessment can relate to the following topics:

- Identifying goals and exhibiting willingness

- Defining roles and creating work plans

- Interpersonal relationships

- Accepting responsibility for teamwork

- Resource-sharing

- Assessing and reviewing performance.

6. Assessment module: In order to assess learning through the PJBL-SCRUM, the teacher uses a qualitative rubrics evaluation form. The learners are evaluated by the teacher and the class participants, including reflection and the exchange of ideas with regard to their performance in order to improve themselves for future learning processes and the final product outcome. The assessment can be divided as follows:

- System efficiency PJBL-SCRUM (online) by 10 experts

- A 360-degree assessment of teamwork skill associated with the teamwork assessment by teachers, students, team members, and a third party [24]

- Project quality assessment.

All use the assessment form using a five-level rubric scoring tool, consisting of holistic [25] and analytical scores determined by the teacher and stakeholders.

\subsection{Phase 2: Evaluating the suitability of the learning process for promoting teamwork using PJBL and the concept of Agile software development}

This phase evaluates the suitability of the design for computer students. The steps for this process are as follows: 1) Create a tool for evaluating the process. 2) Propose the development of the process to 10 experts who hold doctoral degrees, work as lecturers at universities, have at least 10 years' relevant experience, and are experts in the field of technological education. These experts consider and evaluate the suitability of the process. 3) Analyze the results of the evaluation of the process by using mean $(\bar{x})$ and standard deviation (S.D.) measures. A five-point Likert scale is used to assess the appropriateness of the process. The results of the suitability of the learning process model of critical inquiry through digital storytelling in order to enhance digital literacy, as evaluated and certified by 10 experts, are as follows (Tables 4-6). 
Table 4. Results of the suitability assessment of the steps of the PJBL module

\begin{tabular}{|l|c|c|l|}
\hline \multirow{2}{*}{\multicolumn{1}{|c|}{ Evaluated contents }} & \multicolumn{2}{|c|}{ Evaluation outcome } & \multirow{2}{*}{ Level of agreement } \\
\cline { 2 - 3 } & $(\overline{\boldsymbol{x}})$ & $\boldsymbol{S}$. D. & \\
\hline 1. Project topic & 4.90 & 0.32 & Strongly agree \\
\hline 2. Reviewing documents & 4.90 & 0.32 & Strongly agree \\
\hline 3. Planning and drafting & 4.80 & 0.42 & Strongly agree \\
\hline 4. Working process & 4.90 & 0.32 & Strongly agree \\
\hline 5. Writing the report & 4.90 & 0.32 & Strongly agree \\
\hline 6. Presentation & 4.90 & 0.32 & Strongly agree \\
\hline Total mean & 4.88 & 0.33 & Strongly agree \\
\hline
\end{tabular}

Table 4 shows that the experts strongly agree overall in terms of the PJBL (with a total mean of 4.88). Most of the experts agreed that the Project topic, Reviewing documents, Working process, Writing the report, and Presentation $(\bar{x}=4.90)$ were suitable. This information demonstrates that the experts agreed that Planning and drafting was the step that was awarded the lowest rating $(\bar{x}=4.80)$.

Table 5. Results of the suitability assessment of the concept of Agile software development

\begin{tabular}{|l|c|c|l|}
\hline \multirow{2}{*}{\multicolumn{1}{|c|}{ Evaluated contents }} & \multicolumn{2}{c|}{ Evaluation outcome } & \multirow{2}{*}{ Level of agreement } \\
\cline { 2 - 3 } & $(\overline{\boldsymbol{x}})$ & S.D. & \\
\hline 1. Product backlog & 4.60 & 0.54 & Strongly agree \\
\hline 2. Sprint planning & 4.80 & 0.42 & Strongly agree \\
\hline 3. Sprint backlog & 4.75 & 0.42 & Strongly agree \\
\hline 4. Daily Scrum & 4.88 & 0.33 & Strongly agree \\
\hline 5. Sprint review & 4.97 & 0.11 & Strongly agree \\
\hline 6. Sprint retrospective & 4.82 & 0.39 & Strongly agree \\
\hline Overall Result & 4.80 & 0.39 & Strongly agree \\
\hline
\end{tabular}

Table 5 shows that the experts strongly agreed overall with regard to the learning process of the concept of Agile software development (with a total mean of 4.80). Most of the experts agreed that Sprint Review $(\bar{x}=4.97)$ was suitable. This is followed by Daily Scrum $(\bar{x}=4.88)$. This information demonstrates that the experts agreed that Product Backlog was the step that was awarded the lowest rating $(\bar{x}=4.60)$. 
Table 6. Results of the suitability assessment of the learning process for promoting teamwork using PJBL and the concept of Agile software development

\begin{tabular}{|l|c|c|l|}
\hline \multirow{2}{*}{\multicolumn{1}{|c|}{ Evaluated contents }} & \multicolumn{2}{c|}{ Evaluation outcome } & \multirow{2}{*}{ Level of agreement } \\
\cline { 2 - 3 } & $(\overline{\boldsymbol{x}})$ & $\boldsymbol{S . \boldsymbol { D } .}$ & \\
\hline 1. Preliminary conceptual framework & 4.60 & 0.54 & Strongly agree \\
\hline 2. Preparation process & 4.80 & 0.42 & Strongly agree \\
\hline 3. Grouping process & 4.75 & 0.42 & Strongly agree \\
\hline 4. Project-based learning process & 4.88 & 0.33 & Strongly agree \\
\hline 5. Agile working process as Scrum framework & 4.97 & 0.11 & Strongly agree \\
\hline 6. Teamwork skill process & 4.82 & 0.39 & Strongly agree \\
\hline 7. Assessment & 4.80 & 0.44 & Strongly agree \\
\hline 8. Suitability of PJBL-SCRUM model & 4.65 & 0.50 & Strongly agree \\
\hline Overall Result & 4.80 & 0.39 & Strongly agree \\
\hline
\end{tabular}

Table 6 shows the overall result with regard to the suitability of the learning management model of the learning process for promoting teamwork using PJBL and the concept of Agile software development for computer students was at the highest level, with a mean score of 4.80 and a standard deviation of 0.39 . When considered separately, it was found that the Agile working process as part of the Scrum framework module was rated at the highest level $(\bar{x}=4.97$, S.D. $=0.11)$, followed by the Project-based learning process and the Teamwork skill process, respectively.

\section{Summary}

The result of the assessment of the Design of a Learning Process for Promoting Teamwork using PJBL and the Concept of Agile Software Development by experts, was that the experts commented that the Agile working process as part of a Scrum framework module is appropriate as shown by the Strongly Agree rating. They further suggested that it is a model that focuses on students working together as a team and meeting regularly. They noted that it is flexible, which helps learners to achieve a good learning potential. Motivation and stimulation for interest, training to think logically, systematically and step-by-step, help the students to be assertive. It promotes the exchange of knowledge between learners and enhances relationships and good friendship among the learners. This is consistent with the research by Jurado-Navas and MunozLuna who published an article entitled the Scrum Methodology in Higher Education: Innovation in Teaching, Learning and Assessment [9]. They noted that it is a process of creative learning and teaching that can develop the learners by providing them with the skills of knowledge and emotional skills needed in the future. Besides, the experts commented that the PJBL process module is appropriate in that it is rated Strongly Agree. Synthesized steps can be combined with Agile working process as a Scrum framework module. Consequently, the learners will have the opportunity to develop innovation and teamwork skills.

The Design of a Learning Process for Promoting Teamwork using Project-Based Learning and the Concept of Agile Software Development was developed by incorporating the PJBL process and Agile Software Development. It was found that if both 
processes are integrated, this will encourage an in-depth understanding of specific content areas, increase student motivation as well as student attention and focus, develop students' critical thinking and higher-order cognition, build students' confidence, encourage students through the exchange of ideas and information, and building positive and rewarding relationships among students. The teacher will act as a motivator, give advice and counsel in such a way as to strengthen the thinking process, increase creativity, improve decision making, collaboration and presentation due to the integration of various methods, resulting in deep learning based on real experience.

The developed model can be applied to the courses that the teacher wants the learner to progress in, or a course involving PJBL management in next phase of research. The researcher will use the developed model to develop the online PJBL-SCRUM system in order to use it to support teaching and learning according to Learning Process for Promoting Teamwork using PJBL and the Concept of Agile Software Development. The researcher will experiment with learners in order to further test the efficiency of the developed model.

\section{$7 \quad$ Acknowledgement}

The researchers would like to express sincere gratitude and deep appreciation to their instructors in the Department of Computer Education, Faculty of Technical Education, as well as to the experts who participated in discussions. We would also like to thank the National Research Council of Thailand (NRCT) for their generous sponsorship under the Capacity Building Program for New Researchers 2018. Thank you again to the authors of the research articles, case studies, textbooks, and other useful sources of information that we consulted as part of our study.

\section{$8 \quad$ References}

[1] World Economic Forum. (2016). New Vision for Education: Fostering Social and Emotional Learning through Technology, 4-5, retrieved from http://bit.ly/2NWzer3

[2] Kanbul, S. \& Uzunboylu, H. (2017). Importance of Coding Education and Robotic Applications for Achieving 21st-Century Skills in North Cyprus. International Journal of Emerging Technologies in Learning, 130-131. https://www.onlinejour nals.org/index.php/i-jet/article/view/6097/4264. https://doi.org/10.3991/ijet.v12i01. $\underline{6097}$

[3] Cavus, N. \& Uzunboylu, H. (2009). Improving Critical Thinking Skills in Mobile Learning. Procedia Social and Behavioral Sciences, 1(1), 434-438. https://doi.org/10. 1016/j.sbspro.2009.01.078

[4] Resnick, M., Kafai, Y., Maloney, J., Rusk, N., Burd, L. \& Silverman, B. (2003). A Networked, Media-Rich Programming Environment to Enhance Technological Fluency at After School Centers in Economically-Disadvantaged Communities. Proposal to National Science Foundation.

[5] Bell, S. (2010). Project-based Learning for the 21st Century: Skills for the Future. The Clearing House, 83(2), 39-43. 
[6] Boon, A. et al. (2013). Team Learning Beliefs and Behaviours in Response Teams. European Journal of Training and Development, 37(4), 357-379. https://doi.org/10. $1108 / 03090591311319771$

[7] Helm, J.H. \& Katz, L.G. (2000). Young Investigators: The Project Approach in the Early Years (3rd ed). New York: Teachers College Press.

[8] Schwaber, K. \& Sutherland, J. (2018). The Scrum Guide. www.scrumguides.org/ scrum-guide.html

[9] Highsmith, J. (2001). Manifesto for Agile Software Development, retrieved from https://agilemanifesto.org/

[10] Sales, E., Shuffler, M., Thayer, A., Bedwell, W. \& Lazzara, E. (2015). Understanding and Improving Teamwork in Organizations: A Scientifically based Practical Guide. Human Resource Management, 54(4), 599-622. https://doi.org/ $\underline{10.1002 / \mathrm{hrm} .21628}$

[11] Alberts, D.J. (2007). A Model of Multidiscipline Teams in Knowledge-creating Organizations. Team Performance Management, 13(5/6), 172-183. https://doi.org/ $10.1108 / 13527590710831873$

[12] Fatema, I. \& Sakib, K. (2017). Factors Influencing Productivity of Agile Software Development Teamwork: A Qualitative System Dynamics Approach. 24th AsiaPacific Software Engineering Conference, 4-8 December 2017, Nanjing, China. 737-742. https://doi.org/10.1109/apsec.2017.95

[13] Monchai, T. (2011). Courseware Design and Development for CAI. Bangkok: King Mongkut's University of Technology North Bangkok Publishers, 42-46.

[14] Defined Learning. (2007). Project-Based Learning, retrieved from http://bit.ly/2Y1r A3g

[15] Prencipe, A. \& Tell, F. (2001). Inter-project Learning: Processes and Outcomes of Knowledge Codification in Project-based Firms. Research Policy, 30(9), 1373-1394. https://doi.org/10.1016/s0048-7333(01)00157-3

[16] Laisema, S. \& Wannapiroon, P. (2013). Design of Collaborative Learning with Creative Problem-solving Process Learning Activities in a Ubiquitous Learning Environment to Develop Creative Thinking Skills. 5th World Conference on Educational Sciences - WCES 2013. https://doi.org/10.1016/j.sbspro.2014.01.867

[17] Hicks, M. \& Foster, J.S. (2010). Adapting Scrum to Managing a Research Group. College Park, USA, University of Maryland, retrieved from http://www.cs.umd. edu/ mwh/papers/score.pdf.

[18] Jurado-Navas, A., Muñoz Luna, R. \& Taillefer de Haya, L. (2014). Scrum Methodology in University Classrooms: Bridging the Gap Between Academia and the Business Eorld. In: Sánchez Sáinz-Trápaga C, (ed.) Experienciasen la Adaptación al EEES. Madrid: McGraw Hill, 327-335.

[19] Katz, L. \& Chard, S.C. (2000). Engaging Children's Minds: The Project Approach (2nd ed.) New Jersey: Ablex Publishing Corporation.

[20] Stix, A. \& Hrbek, F. (2006). Teachers as Classroom Coaches: How to Motivate Students Across the Content Areas. ASCD, cited in Learning and Teaching.

[21] Puttida, S. \& Krich, S. (2016). The Development of Web-Based Instruction (WBI) for Competency-Based Principle in the Course of Computer Animation with ProjectBased Learning Method through Cloud Computing, 2017-1 International Conference on Applied Computer Technology and Information Systems. 
[22] Davis, C. (2011). How to Assess Networked Project-Based Learning Projects, retrieved from https://us.iearn.org/professional_development/multimedia/assess/ projbased_learning

[23] Sutherland, J. \& Scrum Inc. (2019). The Scrum At Scale ${ }^{\circledR}$ Guide, retrieved from https://www.scrumatscale.com/scrum-at-scale-guide-readonline/\#Getting_Started_ with_ScrumScale

[24] Ruadcharoen, C. (2007). 360 Degree Evaluation between Faculty of Education. Mahasarakham: Mahasarakham University and Mueang Mahasarakham, Municipality Publishers, 15-19. https://doi.org/10.12980/apjtd.7.2017d6-370

[25] Sirasukhon, K. (2007). Rubric or Rubric Scoring. Bangkok Bureau of Academic Affairs and Educational Standards Publishers, 30-36.

[26] Antonio, J. \& Rosa, M. (2017). Scrum Methodology in Higher Education: Innovation in Teaching, Learning and Assessment. International Journal of Higher Education. 6(6), 1-2.

[27] Pinanta, C. \& Prachyanun, N. (2017). A Web-based Learning System using Projectbased Learning and Imagineering International Journal of Emerging Technologies in Learning, 4-22. https://doi.org/10.3991/ijet.v12i05.6344

[28] Jacques, S., Bissey, S. \& Martin, A. (2016). Multidisciplinary Project Based Learning Within a Collaborative Framework International Journal of Emerging Technologies in Learning, 36-44. https://doi.org/10.3991/ijet.v11i12.5996

\section{Authors}

Puttida Sakulviriyakitkul is a Ph.D. student in the Department of Computer Education, Faculty of Technical Education, King Mongkut's University of Technology North Bangkok (KMUTNB), Thailand (e-mail: puttida0103@gmail.com). She also works as a special instructor at the King Mongkut's University of Technology North Bangkok (KMUTNB), Thailand.

Krich Sintanakul is an assistant Professor at the Department of Computer Education, Faculty of Technical Education, King Mongkut's University of Technology North Bangkok (KMUTNB), Thailand (e-mail: krich.sin@gmail.com). He has been working as a teacher for more than 20 years in the field of information technology and computer education at Faculty of Technical Education at the King Mongkut's University of Technology North Bangkok (KMUTNB), Thailand.

Jiraphan Srisomphan is an assistant Professor at the Department of Computer Education, Faculty of Technical Education, King Mongkut's University of Technology North Bangkok (KMUTNB), Thailand (e-mail: jiraphan.s@fte.kmutnb.ac.th). He has been working as a teacher for more than 20 years in the field of information technology and computer education at Faculty of Technical Education at the King Mongkut's University of Technology North Bangkok (KMUTNB), Thailand.

Article submitted 2019-03-14. Resubmitted 2019-08-19. Final acceptance 2019-11-06. Final version published as submitted by the authors. 